\title{
The growth of the holiness of Mary: From flat character to theological construct
}

\author{
Joubert, Lisel \\ Stellenbosch University \\ lisel@kingsley.co.za
}

\begin{abstract}
This article deals with how a flat character in a biblical narrative could grow and assume a life of its own that becomes the example par excellence of holiness for many believers throughout the ages. Inspired by the work of B. R. Gaventa and her narrative reading of the Gospel texts and exploration of the characterisation of Mary, I would like to explore the dynamic of reception history and the changing criteria for holiness. I will consider the phenomenon of characterisation in narratives, the blurring of lines in interpretation and how a character in a narrative, which is an artificial construct, is taken out of that context and placed in contexts determined, in a sense, by generations of 'new narrators' with changing understandings of holiness.
\end{abstract}

Key words

Spirituality; narrative criticism; reception history; Mariology

\section{Introduction ${ }^{1}$}

Why Mary? Reams have been written on Mary from a multitude of angles and perspectives. I am not assuming that this article presents something brand new and earth-shattering. Rather, it is born out of a fascination with the imaginative process that comes into play between the telling and writing of a narrative and the ongoing development of a character outside of the narrative. In this instance the focus is on the progress of the Mary of the gospels, who becomes the epitome of holiness, and how this process influenced different traditions of spirituality.

1 This article is based on a paper delivered at the SPIRASA conference in Johannesburg, May 2015. The theme of the conference was 'Holiness' 
Influenced by the work of Beverly Gaventa $(1999)^{2}$ the main lens of this paper is a literary one. Mary will be revisited as a character in a narrative or, to be more precise, more than one narrative. This article does not endeavour to find the 'real' or historical Mary. Nor is the focus the theological implications of the events that are ascribed to her for us today. Rather the article aims to understand her as a literary character in a narrative (or rather narratives) that assumed a life of her own in subsequent narratives. In tracing this development I also invite further thought on the role of Mary in Reformed theology, where tradition and Scripture play another type of role, as well as looking at the role of imaginative interpretation that defines the concept of holiness for subsequent generations. The article does not aim to present an in-depth new theological understanding of Mary but rather traces the role of interpretation in order for us to understand what happened to Mary, the character in the gospels, and ponder possible new readings for our context.

\section{Mary as a character}

It is probably easier to discuss a character if you only have one novel or one short story. The moment you have more than one narrative of the same so-called event, and these narratives share the same characters, it gets trickier, especially if these narratives are found in sacred literature and are presented as salvation history. In looking at Mary as a character the reader needs to accept that there is more than one source.

It gets even more complicated when using texts born from an oral culture and containing narratives of the same events but being presented in vastly different ways to different audiences (Synoptic gospels and John). The first narratives had different audiences and subsequent generations of religious communities took these different narratives and mixed them into a new whole which one experiences in any Christmas play that places, without blushing, the Magi and the shepherds on the same stage.

In his book Narrative Art in the Bible (1989) Shimon Bar-Efrat reminds us that this is actually a typical biblical phenomenon. We only have to read the

2 Gaventa (1999:3) speaks about different quests for Mary: Historical, theological and literary. 
stories where David is a character in Chronicles and the Books of Samuel to find more than one David.

The article will now set out to meet Mary in different narratives. The bigger narrative context is important, as Gaventa (1999:22) reminds us that Mary and other characters in the gospels were portrayed as characters mainly in the presentations of Jesus' story. If we didn't have the story of Jesus we would have no Mary. But which Mary do we have?

Before we meet Mary it is necessary to reflect on the role of characterisation in narratives, especially biblical narratives. Any literary character is an artificial construct drawn from or relatively imitative of people in the real world (Gaventa 1999:20). The identity of the character becomes known primarily from the continuity of his/her own speeches and acts that constitute the kind of person presented. This is heightened or reinforced by the actions towards the character by other characters.

Basic literary character analysis teaches us that any narrative has different types of characters that make up the story. We can distinguish between round and flat characters, protagonist and antagonist. Round characters have depth and they change. Flat characters are needed for narrative to progress.

Round characters are seen as 'real' people (Kingsbury 1986:10)! What Kingsbury means is that such a character is multi-layered and shows complex traits. A flat character has fewer traits and is more predictable in behaviour. Kingsbury (1986:10) also speaks of 'stock' characters, who possess only one trait or are brought into the narrative as an example of something, e.g. 'the leper' in the Gospels.

In her work on Old Testament narratives Adele Berlin (1983:23) distinguishes three types of characters. She identifies the full-fledged character, she calls the flat character the type and she also identifies the functionary character, namely the agent. Berlin (1983:23) described these characters as follows: the agent is the one about whom nothing is known except what is necessary for the plot; the type has a limited and stereotyped set of traits; and we know more about the full-fledged character than what is necessary for the plot. For example, in the 2 Samuel 11-12 narrative, she would describe Bathsheba as an agent. She exists for the plot. Reading this narrative, one 
realises that she never speaks (except to send a message to David to inform him of her pregnancy) and is acted upon. On the other hand, one only needs to look at art through the ages, to realise what has become of Bathsheba: A sexy woman seducing David. A probable rape scene is rather imagined as a seductive encounter because of patriarchal stereotypes, and because she is not a full-fledged character she cannot defend herself (and had to wait for feminist biblical scholars to do that).

Working mainly on the Old Testament, Berlin (1993) continues that, typical of biblical characters, they are not described in order for an audience to visualise the character (physical attributes) but rather: '...to enable him to situate the character in terms of his place in society, his own particular situation, and his outstanding traits' (Berlin 1993:36).

Kingsbury further (1986:9) writes that a narrator has two options when bringing a character into life: one is "showing" by having characters act and speak for themselves or having other characters talk about them, or the author can have the narrator "tell" the reader about them. The first is most common in biblical literature.

Looking at Mary as a character Gaventa (1999:21) quotes M.D. Springer: "The life of a literary character thus comes to a close when his or her part of the work is complete." This article wants to ask: What if the life does not come to a close?

In this article I chose to look at Mary in the Gospels of Matthew, Luke, John and the Book of Revelation. Chronologically speaking the gospels are not first but form the focus of the article because of their narrative character. It is their stories that play the biggest role in the imagination of interpreters that becomes an inherent part of the ongoing reception history through the ages.

Two things will happen with each narrative. Firstly, certain simple questions will be asked in order to understand the role of Mary as a character in each narrative. The questions are as follows: Does she speak? Does she act? Does she make a decision? Is she acted upon? Is she necessary for the overall plot of the narrative? Does she change?

Secondly, certain words, phrases and moments in the narratives surrounding Mary as character will be identified. This will be presented 
as the fodder ${ }^{3}$ for imagination which influenced further retelling and interpretation. I use fodder as a word to denote the basic information or material needed to work with in re-imagining a character or narrative.

\subsection{The Gospel according to Matthew}

In light of the above questions and reading the infancy narratives of Matthew 1-2, we note the following: Mary does not speak. She does not take initiative to act. She does not make any decisions. She is acted upon, in the sense that decisions are made for her. She is definitely necessary for the plot and becomes welded to her child ('child and his mother' e.g. 2: 14, 21). She does not change.

Answering the second question: 'What words, phrases, symbols are used in telling the events surrounding her that sparked an interpretative imagination and triggered new narratives?' we note the following. The one most probable word or concept that took on a symbolic meaning of its own is the word 'virgin' (1:23).

Most theologians are aware of the well-known difficulty in understanding this description of Mary. In a sense it is not what was 'lost' in translation but rather what was 'found'. In Isaiah 7:14 the Hebrew reads almah or young woman, while the LXX reads parthenos or virgin. It is this Greek translation that is found in Matthew 1:23 which becomes the cornerstone of a whole imaginary symbolic construct of Mary as virgin. Gaventa (1997:47) writes: 'For Matthew, the most important function of Mary is to fulfil this prophecy' - the prophecy of the parthenos.

In literary terminology we can describe Mary in The Gospel of Matthew as a flat character. Berlin (1986) would call her an agent. Almost like

3 The word fodder just sprang to mind, ironically as I read the following on a website discussing flat characters: 'Imagine you're watching an episode of the original Star Trek. A landing party beams to a hostile alien world. There's Captain Kirk - tough guy, loyal friend, skirt chaser. There's Spock - logical, self-sacrificing and sometimes surprisingly human. And then there's the guy in the red shirt. When the aliens show up to fight, you know Red Shirt is going to get it, and you don't care because you hardly know him. There's nothing to know about him! He is a flat character, one who can be fully described in a single sentence. In this case all you need is two words, 'cannon fodder.' (http://study.com/academy/lesson/round-flat-character-definition-examples.hyml) Retrieved 2015/ 05/05 
Bathsheba, we do not get to know her. We know what happens to her and she is mostly understood in relation to the 'child', her son: 'Mary's exclusive role in Matthew is that of Mother' (Gaventa 1999:46).

Interestingly, reading 'Matthew as story' by Kingsbury (1986), in his list of characters and discussion of characterisation, Mary is only mentioned by name in his list of 'Minor characters'. These characters are described as 'appear[ing] briefly in a scene and then vanish[ing]' (Kingsbury 1986:25). As character the focus is on her motherhood.

In her literary reading Gaventa looks at the bigger context of the genealogy in Matthew 1 and the four women included there. Mary is a threat for Joseph within the social context and is being threatened in return. This she shares with the other women, namely Tamar, Rahab, Ruth and Bathsheba or 'the wife of Uriah'. She is an endangered figure constantly under the threat of destruction (Gaventa 1999:46)

\subsection{The Gospel according to Luke}

In Luke 1-2 Mary comes the nearest to being a full-fledged character of all the gospels. She speaks; she acts; she makes an important decision; She is acted upon (one can query whether her pregnancy is portrayed with or without her consent?). Mary is necessary for the plot. Through her affirmation she changes from a surprised young girl to a powerful prophet and mother of a saviour.

If a character is understood in the light of what others say about the character as well as what the character does and says, what do we learn about Mary? The angel calls her 'favoured'. Some translations add 'blessed are thou amongst women' (Luke 1:28 KJV). She herself refers to the fact that she has not been with a man, but we also meet her as somebody who accepts God's hand in her life. She also names herself in her song (the socalled 'Magnificat') and calls herself blessed; and it is this understanding of herself that will colour the understanding of subsequent generations. She also refers to herself as the 'handmaiden' or 'servant' of the Lords, depending on translations of Luke 1:38 (Greek: doule; Latin: ancilla).

Mary is therefore described as favoured before she has even heard what it is all about. She is presented as somebody to whom God's presence is promised. She is called to become a mother. She accepts her call and 
thereby she is characterised as somebody who sees herself as blessed and willing to be the 'servant/slave/handmaiden' of the Lord.

What words, phrases or parts of the plot in the Luke narrative gave fodder for subsequent imagination? The fact that Mary is visited by an angel. For the Jewish audience this event stands in line with similar events in Old Testament narratives where God spoke to barren women through angels and promised new life. The visit and the words of the angel, that became the 'hail Mary', formed subsequent imagination. Not only the annunciation but also the content of her consent fuelled the imagination ('fiat' became a word on its own because of Latin, 'Ecce ancilla Domini; fiat mihisecundum verbum tuum'). Mary's character is formed by what the angel calls her, her words of consent and the words she uses to name herself: "for, behold, from henceforth all generations will call me blessed" (Lk 1:48). The other moments in the narrative that fuel subsequent interpretation and imagination are the words of Simeon in the temple: "....and a sword will pierce your own soul too." (Luke 2:35)

In Luke we are given a character which makes a choice and owns a voice. Still we do not know more of Mary than is needed for the narrative. Her presence is there to give insight into how God works in the birth of Jesus. Mary is identified as mother, prophet and disciple. Perry (1996:63) writes: "In Luke/Acts Mary emerges as a major character. She is not an afterthought, there by virtue of the accidents of birth - and "after all, somebody had to be Jesus' mother." Neither is she a plot device highlighting her husband's character."

Gaventa (1999:73) identifies her role as disciple, prophet and mother and makes the comment that although these roles are interwoven we need to distinguish them and clarify each; otherwise, "we will once again flatten Mary's character and reduce her to a single feature or one function." Gaventa (1999) proposes and reminds the reader that Mary needs to be truly a character and not just a symbol or type.

\subsection{The Gospel according to John}

In the gospel of John we find Mary as the mother of an adult son at the scene of a wedding festival where they are invited guests (Jn 2). She is not called by her name, she is his 'mother'. In the scene at Cana Mary does 
speak. She acts by taking command of a potentially humiliating situation. She makes a decision and takes initiative when it seems to her that her son is not going to do anything. She is acted upon because a first reading of the text can give the reader a feeling that her opinion doesn't count: "Woman, what concern is that to you and to me?" (Jn 2:4). In this event at Cana she is crucial to the narrative. Did she change? No, she is presented as an active character but not complex. She is the character who initiates action.

John is also the only gospel where Mary is present in the crucifixion narrative. There she does not take any active role but is presented as Mother to the disciple whom Jesus loved. She does not speak, is acted upon but is crucial to the moment.

Gaventa (1999:96) writes: "Mary's role in the Gospel of John consists exclusively of her relationship to Jesus. She remains unnamed because what makes her important is nothing other than the fact that she is Jesus' mother." Gaventa (1999) proposes that Mary is not essential to the narrative, for any character could have set the scene where Jesus demonstrates his earthly connectedness and then a separation from that connectedness.

\subsection{The Book of Revelation}

In the Book of Revelation the reader is confronted with a different symbolic world. The motivation for considering Revelation as well in this article is because of later interpretations which identified Mary as a character in the visionary scenes. Although this interpretation is challenged by some modern New Testament scholars, it helps to understand the imaginative process behind the life of Mary after the texts.

Revelation is apocalyptic and steeped in symbolism. In the midst of the visionary character of the descriptions we read the following, in Revelation 12:1-2: "...a woman clothed with the sun, with the moon under her feet, and on her head a crown of twelve stars. She was pregnant and crying out in birth pangs".

No clear identification is made to Mary in the text. Most interpreters see this as a symbolic reference to the Church. However, this scene in the heavens has all the elements to become excellent fodder for the imagination and played a crucial role for subsequent generations in their description of Mary as 'Queen of heaven'. 
If we have to sum up all the above, what do we have? We have a character who is mostly flat, does round out in Luke, but who is surrounded by words and themes that spark imaginative interpretation, making it possible for generations of believers to construct a new character or construct out of that which has triggered their imagination.

In the rest of the article I will focus on how these Gospel narratives formed the basis of interpretative texts that lead to a specific understanding of holiness. In the narratives Mary is never called holy, so how did this attribute become so central in further interpretations and retellings?

\section{Imagination and interpretation}

What happens with a character when she assumes a life of her own? One can start with what we know about the way Scripture was interpreted in the early church - and the type of exegesis that was seen as the norm. It is important to realise that all types and methods of interpretation happen within a dynamic situation. Mills (2003:3) writes that imagination engages with the poetic and metaphorical nature of biblical language. She talks about the interaction between the world that produces Scripture and also Scripture that produces the world; because the Bible is full of imagery and metaphor, there can be a plurality of meanings.

Within the rabbinic and midrashic ${ }^{4}$ modes of interpretation, every word or sentence has the potential of opening up a world of its own. To add information or recreate the narrative is not seen as obviously 'heretical'. It is also true that most forms of interpretation or rewriting are done because a new situation or question has arisen that needs to be addressed, and a certain theological conviction has to be presented in a specific situation. Paul does this in Galatians when he takes the Old Testament Biblical characters of Hagar and Sara and places them in a symbolical argument, changing these two characters into types. The women we meet in Galatians therefore relate to the women in Genesis solely by name. Gaventa (1999:105) helps to

4 Gruenwald (1993: 6) supplied a useful definition of midrash as quoted in Kruger, 'References to women of the Old Testament in the Demonstrations of Aphrahat the Persian Sage', namely as midrash 'a form of cognition that supplies terms of reference and channels of perception for people who organize their lives in accordance with a scriptural world of ideas'. 
explain this: "One prominent contemporary literary theory contends that narratives can be analysed in terms of need that must be overcome".

In a world where believers come from different interpretive traditions (Jewish and Greek) a variety of interactions are possible. Some examples will follow. In the second century Jewish-Christian apocalypse the Ascension of Isaiah we meet a character with the name Mary who had a miraculous delivery after looking up and seeing a little child. This Mary had a delivery without pain, womb intact, perfectly virgin in partu (Perry 1996:124). In the Second Century Odes of Solomon it is told of Mary “... and bore a son without feeling pain" (Perry 1996:125).

In the other second century text that actually created a bigger symbolic world than the Gospel texts, namely the Protevangelium of James, we meet a character with the name Mary, whose parents Anna and Joachim (who became saints) couldn't have children. This Mary is subsumed under the concept of ritual purity. Gaventa (1999:114) calls this sacred purity. Mary becomes a function of the purity rather than its being a characteristic of her. She is seen as a sacred figure set aside for God, in that sense holy.

According to Gaventa (1999:114) a reader who knows only the Protevangelium might reasonably conclude that Mary is the holy figure and that Jesus' holiness derives from her. That is a far cry from the Mary we meet in the gospels, where holiness or purity is not even mentioned by name. Imaginative interpretation deduced these adjectives from the concept of virginity, which then became part of the bigger Christological debates.

Perry (2006:145) refers to Jaroslav Pelikan's explanation of the types of exegesis that happened in the first centuries which is referred to as the development of doctrine by extrapolation, or a "reapplication of the hermeneutic of "prophecy-fulfilment" from the Old Testament to the New Testament to the Church. In such readings Old Testament assumptions are read into situations as plausible explanations.

We can explain the new life of a character if we understand the way texts were understood and used in the context during and after the New Testament times.

But then there is also the more philosophical explanation, where human imagination comes into play, where new worlds are created but one 
struggles to explain them. Mills (2003:6) talks about the "windows of imagination [which] open up vistas on that which is beyond immediate daily experience"; an example would be this concept of pre, ante and post-partum virginity. Mills (2003:6) quotes Paul Avis who writes that: "Narrative is a creative, idealised and stereotyped relation of the paths and journeys on which individuals and communities find themselves", as found, for example, in the third century Christianity. When does a character become life-changing? When she reflects the stereotype of the context or confronts the context with a brand new event?

Paul Ricoeur (1995) also wrote on the Bible and imagination. He talks about imagination as the "power of re-describing reality" (1995: 144). For him narratives offer "a remarkable example of the conjunction between fiction and re-description" (1995:145). This refers to the constant influence a narrative, especially a religious narrative, has on the context and vice versa.

What happened to Mary as a character is that there was a period of no interest in her as such. In the second century some themes began to surface, namely her maternity, virginity, sinlessness and an introduction of a typological reading where Mary becomes the Second Eve who counters the disobedience of the First Eve (e.g. Irenaeus and the theory of recapitulation). In the context of the early church where one finds an ever-growing patriarchal undergrowth and a move to celibacy, interpreters zoomed into the fodder of narratives which could strengthen stereotypes to promote a certain lifestyle. The Holy Mother who was so exceptional as to be a virgin ante-, pre- and post-became the source of liturgy and prayer, and later the above-mentioned earthly Queen of Heaven.

In Christian interpretation and traditions one finds a typical chickenand-egg scenario. Liturgy, prayer and religious feasts informed popular imagination and imagination informed liturgy, prayer and feasts. Symbols, words and moments that were part of a story or narrative assumed a life of their own and became constructs that generated ever new narratives.

In the life of a character one recognises several factors that come into play: the types of acceptable interpretation, the oral character of the culture, the authority of tradition, the world view of the audience, the cultural expectations of the audience, etc. David Brown (1999) in his book 'Tradition and Imagination' takes a stand for the positive role of tradition 
and the authority of subsequent imaginative interpretation of texts. Some of his arguments can be questioned.

Brown writes (1999:2): "Present-day Christianity, it seems to me, will go badly wrong, if it attempts an unmediated dialogue with the biblical text rather than recognizing also the intervening history that has helped shape its present perception of the text's meaning." With that one can still concur, but then he goes on to write that as the gospel writers rewrote the birth of Jesus towards the end of the first century "so the later Church continued this process, and in so doing improved upon the contents of the original narratives" (Brown 1999:76). I am a bit too much of a biblical scholar to imagine one can improve on Scripture.

With regards to the virgin birth Brown (1999:77) writes:

'Even the Virgin Birth's primary import is not to tell us anything about Mary, but rather to indicate the absolute priority of God's action and thus that the Spirit-filled child will become a Spiritempowered adult, with all that implies. When therefore the incident of Salome the midwife is invented, we are not yet in another world: the attitudes and assumptions are the same. It is merely one way of giving added emphasis to the idea of the supernatural power of God totally directing all that is still to come, and that seems to me so even with respect to the legends of Mary's childhood and marriage. The interest, at least to begin with, is not with her in her own right, but in reinforcing the sense of anticipation: Mary's presumed holiness adds to the wonder of what is yet to come.'

The fact is that different generations are inspired by different things and ask different questions. One can say that what inspired a second or thirteenth century audience does not necessarily inspire today.

For David Brown (1999:104), the power of revelation is not necessarily undermined if external material from surrounding culture is used to rewrite the story. But what happens if the character loses her impact?

John De Gruchy (2013:26) also writes on the role of imagination and theology, arguing that imagination has long been regarded as "an inadequate and unreliable mode of knowledge, in contrast to reasonable, logical or empirical discourse". Modern science however helps us to understand how 
crucial imagination is: "Imagination is not the fanciful creation of absent meaning, a thumb-sucking exercise as it were; it functions within the matrix of memories or traditions that have shaped our lives..." (De Gruchy 2013:27).

For De Gruchy the retrieving and transforming of tradition are important one might even say, the retrieving of characters. But even when one chooses to retrieve a tradition there is also a subjective element. He writes that it is important to be aware "...how not to miss the transformative potential in trajectories that do not immediately claim one's attention and commitment. The danger is trying to control tradition by selecting only those trajectories that support one's argument" (De Gruchy 2014:46). He realises that we play a role in controlling tradition through our own choice of trajectories or how we chose to let a character live on. For De Gruchy the transforming of tradition through insightful theological imagination is a fundamental task of theology. His insight into imagination is formulated: “'Genuine insight changes us and our perspectives on life, supplementing or even subverting tradition" (De Gruchy 2013: 29). Maybe we must sometimes subvert traditional interpretation to come to the core of subverting truth.

\section{Mary as subsequent character and construct}

What is the danger when imagination takes hold of a character like Mary? Firstly, you take liberties with a character that is not full-fledged and the construct that follows can become the extension of your own ideology, world view, culture, etc. What became of Mary as character in subsequent generations and retellings? The most telling for me is: She lost her name, she became a list of adjectives and nouns: She became the Virgin, the Holy Virgin, The Blessed Virgin Mary, Theotokos, Our Lady etc. One's geographical and theological position determined whether one called her 'mother of God' or 'mother of Christ'. Jerome refers to her as 'a garden enclosed', 'a fountain sealed', 'east gate', all Old Testament concepts in which she is read (Perry 2006:163).

Nestorius called her 'The stainless jewel of virginity', 'the awesome loom of the 'economy' on which the garment of union was woven' (Perry 2006:168). For Bernard of Clairvaux she is the 'Mediatrix'. She is the Queen of heaven. There are feast days surrounding her Immaculate Conception as well as 
assumption (dormition). Maria Lactans, Mater Dolorosa. All these names and events formed spiritualities and concepts of holiness, good and bad.

But there were other concepts surrounding Mary in the Gospel narratives that also could have served as fodder for imagination, namely the scandal surrounding her pregnancy and her role as prophet, being chosen for a task, accepting this task as the prophets of old did and singing a very subversive song. Is it not possible to find her holiness in these modes of characterisation?

She is presented as a girl whose life is threatened by a pregnancy in a specific social context and the jealousy of Herod; an agent who is vulnerable but agrees to a very scary job and calling; a girl who sings a very subversive song, not one that the powerful would like; a vulnerable girl with a powerful calling.

The more holy Mary became in interpretive rewriting and retelling of her character, the less dangerous she became. She was tamed in her holiness. The more exceptional her character and her virginity, the less powerful she became as a character. Mary became sanitised.

Today some feminist and liberationist readings remedy this. Still we have a character that did not disappear but assumed a life of her own. This life is the product of imagination and perception. She becomes an object of perceived holiness, to adore or emulate; but how much is imaginary a construct?

\section{Conclusion}

What do we do with flat characters? We use them without their consent. The full-fledged Mary in Luke we flatten out by ignoring the powerful events of prophetic calling. Imagination and tradition recreated Mary and formed a certain understanding of holiness - an understanding, which in a certain sense, lifted her out of the mundane onto a higher plane of existence. How do characters assume a life of their own? Maybe because of a dynamic interplay of types of interpretation and human imagination, that can invite us to do the same today with Mary as a character. From a Reformed perspective it means going back to the texts and finding the other clear theological trajectories which can be reinterpreted for our own 
context, also in an imaginative way, rooting Mary's holiness in her being chosen into different roles that is linked to life and body.

\section{Reference list}

Bar-Efrat, S. 1989. Narrative Art in the Bible. Sheffield: The Almond Press. Berlin, A. 1983. Poetics and the interpretation of biblical narrative. Sheffield: The Almond Press.

Brown, D. 1999. Tradition and Imagination. Revelation and Change. UK: Oxford University Press.

De Gruchy, J. 2013. Led into Mystery. Faith seeking answers in Life and Death. London: SCM Press.

De Gruchy, J. 2014. A Theological Odyssey. My Life in Writing. Stellenbosch: Sun Press.

Gaventa, B.R. 1999. Mary. Glimpses of the Mother of Jesus. Minneapolis: Fortress Press.

Gaventa, B.R. \& Rigby, C.L. (eds). 2002. Blessed One. Protestant Perspectives on Mary. Louisville: Westminster John Knox Press.

Holness, L. 2008. Journeying with Mary. Wellington: Lux Verbi BM Johnson, E. 2004. Truly our Sister. A Theology of Mary in the Communion of Saints. New York: Continuum.

Kingsbury, J.D. 1986. Matthew as Story. Philadelphia: Fortress Press.

Mills, M.E. 2003. Reading Ecclesiastes. A Literary and Cultural Exegesis. Aldershot: Ashgate.

Perry. T. 2006. Mary for Evangelicals. Toward an understanding of the Mother of our Lord. Downers Grove, Illinois: IVP Academic.

Ricoeur, P. 1995. Figuring the Sacred. Minneapolis: Fortress Press.

Steinberg, M. 1985. The Poetics of Biblical Narrative. Ideological literature and the Drama of Reading. Bloomington: Indiana University Press. 